FILIP GALOVIĆ

\title{
DEKLINACIJA IMENICA U KOMIŠKOMU GOVORU
}

Filip Galović

Hrvatsko katoličko sveučilište

Ilica 242

HR 10000 Zagreb

filip.galovic@unicath.hr
UDK: 811.163.42’282.2(497.5 Komiža)

81'366(497.5Komiža)

Izvorni znanstveni članak

Ur.:2018-10-22

U radu se usmjeruje na morfološku problematiku mjesnoga govora Komiže na otoku Visu, odnosno glavnim je ciljem ukazati na vlastitosti u deklinaciji imenica. $\mathrm{Na}$ temelju se analiziranoga materijala može zaključiti da su osobitosti u deklinaciji imenica opserviranoga govora većinom očekivane za srednjodalmatinsko područje te da nisu uzdrmane najnovijim utjecajima i nanosima sa strane. otok Vis

Ključne riječi: čakavsko narječje, morfologija, deklinacija imenica, govor Komiže,

\section{Uvod}

Nije jednostavno istaknuti sva znanstvena postignuća akademika Milana Moguša. Sama činjenica da je Milan Moguš objavio oko tri stotine znanstvenih i stručnih prinosa mnogo toga kazuje. Najznačajnije područje njegova rada, kako se dobro zna, jest dijalektologija, a posebno se bavio čakavskim narječjem. Ono što mu je zasigurno bilo naročito blisko i čime ulazi u znanost jest govor rodnoga mu Senja, na čemu je doktorirao te 1966. godine u Senjskomu zborniku objavio opsežnu studiju Današnji senjski govor, a čemu se opet nakon nekoliko desetaka godina sustavnije vratio u Senjskomu rječniku iz 2002. godine.

Stari je govor Senja cakavski govor, kao nekoć (a djelomice i danas) stanovit broj čakavskih punktova od Istre pa sve do otoka Visa. Otok je Vis bio i ostao najjužnijom cakavskom točkom. Cakavizam je u određenim viškim govorima evidentirao Malecki, a prvi je opis tih govora objavio Mate Hraste u prilogu Osobine govora ostrva Visa iz 1937. godine. U ovomu se radu osvrće na pojedine morfološke posebnosti u cakavskomu govoru mjesta Komiže na otoku Visu, odnosno u središtu je analize deklinacija imenica. 


\section{Metodologija}

Joško Božanić, rođeni Višanin, profesor na Filozofskomu fakultetu Sveučilišta u Splitu, u dosadašnjem se radu istaknuo "kao pjesnik (pa i sonetni majstor), kao zapisivač i snimatelj usmene književnosti, kao leksikograf, kao dramski autor, kao proučavatelj hrvatske maritimološke leksikografije, kao stilističar, kao dijalektolog. No ponajprije uz njegovo ime vezujemo facende i falkušu". ${ }^{1}$ Pored niza objavljenih priloga, godine 2015. Joško Božanić objavljuje veoma vrijednu knjigu Viški facendijer. Stil, leksik, svijet facende otoka Visa dvadesetoga stoljeća u kojoj donosi sto i jednu facendu s otoka Visa, što ih je prikupljao od 1968. godine pa do novijega vremena. Riječ je o pričama koje obilježava nefikcionalnost i humorističnost, a koje su u knjizi interpretirane s više aspekata. Objavljena građa može poslužiti ne samo za "dijalektološke, lingvističke, leksikografske i stilističke interpretacije, već i kao podloga za interdisciplinarno istraživanje koje može uključiti i druge, nefilološke, discipline kao što su etnologija ili kulturna antropologija". ${ }^{2}$

Dijalektološki su podaci u ovomu članku ekscerpirani iz navedene knjige Joška Božanića. Riječ je o podacima koji su s više strana pouzdani te su kao takvi mogli biti korišteni u raščlambi. Ponajprije, "svi pripovjedači izvorni su govornici viških govora te njihovo kazivanje možemo smatrati reprezentativnim dijalektološkim dokumentima. Prenošenje zapisa iz auditivnog u medij pisane riječi ostvareno je uz maksimalno poštovanje strukture snimljene govorne rečenice". ${ }^{3}$ Osim toga, terenske su bilješke pokazale, kada je materijal to dopuštao, da se premoćnim dijelom podudaraju s onima iz Viškoga facendijera. ${ }^{4} \mathrm{Na}$ koncu, ime profesora Joška Božanića kao autora jamči pouzdanost objavljene građe.

\section{J. LISAC, 2016, 306. \\ J. BOŽANIĆ, 2015, 569. \\ J. BOŽANIĆ, 2015, 14.}

U terenskomu sam radu 2018. godine, što na temelju vlastitoga upitnika, što na temelju nevezanih razgovora, zabilježio brojne podatke o komiškomu govoru. Ispitanicom je bila Davorka (Darija) Skorin (rođ. Dorotić) (rođ. 1946.). Također je u okviru mojega kolegija studentica Lucija Dorotić istraživala govor mjesta Komiže s posebnim osvrtom na leksičku razinu, pa se i njezina pisana građa i više zvučnih zapisa koje je prikupila ukazala vrijednom. Osim navedenoga, imao sam na raspolaganju i neke podatke što mi je prije nekoliko godina bio kazivao Ante (Tonko) Božanić Pepe (rođ. 1947.). 


\section{Imenice u govoru mjesta Komiže na otoku Visu}

Imenicama je u komiškomu govoru relevantna gramatička kategorija roda, broja, padeža i živosti/neživosti. Prema kategoriji roda imenice pripadaju muškomu, ženskomu ili srednjemu rodu. Potrebno je naglasiti da se izvanjezična kategorija spola ne mora uvijek podudarati s gramatičkom kategorijom roda. Gramatički su brojevi jednina i množina. U nekih se imenica ne podudara izvanjezična kategorija brojnosti s gramatičkom kategorijom broja. U oba su gramatička broja ovi padeži: nominativ, genitiv, dativ, akuzativ, vokativ, lokativ, instrumental. Imenica je döba ovjerena kao nepromjenjiva: nüku döba (272), u onö döba (301), u nïku döba (302).

Po kategoriji živosti imenice muškoga roda koje označuju što živo u jednini imaju akuzativ jednak genitivu, a one koje označuju što neživo akuzativ jednak nominativu.

Po kriteriju se nastavka u genitivu jednine razlikuju tri vrste imeničke deklinacije: $a$-vrsta, $e$-vrsta te $i$-vrsta.

\subsection{Imenice a-vrste}

Imenicama $a$-vrste pripadaju imenice muškoga i srednjega roda $\mathrm{s}$ genitivnim nastavkom $-a$.

\subsubsection{Imenice muškoga roda}

U govoru su Komiže muškoga roda imenica minût (354) te imenica tlëh 'tlo' (220).

Imenica covïk (192) ima množinske oblike sa supletivnom osnovom jud-: jûdi (41), jūdîh (55).

Deklinacijski obrazac:

\begin{tabular}{|c|c|c|}
\hline & jednina & množina \\
\hline nominativ & $-\varnothing,-o,-e$ & $-i$ \\
\hline genitiv & $-a$ & $-\varnothing,-i h,-u(v)$ \\
\hline dativ & $-u$ & $-i m a$ \\
\hline akuzativ & $-\varnothing,-a$ & $-e$ \\
\hline vokativ & $-u,-e,-o$ & $-i$ \\
\hline lokativ & $-u$ & $-i m a$ \\
\hline instrumental & $-o n,-e n$ & $-i m a$ \\
\hline
\end{tabular}

5 Svi su primjeri ekscerpirani iz knjige Joška Božanića Viški facendijer. Stil, leksik, svijet facende otoka Visa dvadesetoga stoljeća. Uz pojedini je primjer u zagradama naveden broj stranice na kojoj se primjer nahodi. 


\section{Nominativ jednine}

U nominativu su jednine zabilježeni trojaki nastavci: - $\varnothing,-o,-e$. Prazni je nastavak ovjeren u imenica kojima osnova završava na konsonant: barkêr 'zapovjednik u barci' (65), bilîg 'trag, biljeg' (108), covïk (47), ditmôn 'mladić' (256), dôz 'kiša, dažd' (53), dûźd (39), gãnac 'kuka na drvenoj motki za lov ribe' (59), garbûn 'ugljen' (42), glôś (47), grotâc 'limeno vjedro za vodu' (125), jëmper 'džemper' (363), kajîn 'lavor' (362), kãnat 'pjevanje' (267), kurôj 'hrabrost, odvažnost; 2. dobro raspoloženje' (102), likôr (57), mïśec (51), nöhat 'nokat' (93), plöviśt 'drvo koje more nanese na obalu' (208), popëcak 'žarač' (351), poteśtôt 'gradonačelnik' (156), pulentâc 'vjetar zapadnjak slabijega intenziteta' (51), putïć (95), śîcic (174), śijãvac 'veslač u svjećarici' (65), śijûn 'vihor' (183), śkarpûn 'vrsta morske ribe' (354), śökol (362), śtrôh (359), śūdâc (154), śvićor ' 1 . zapovjednik ribarskoga broda i najčešće vlasnik ribolovnoga alata; 2 . zapovjednik svjećarice (a najčešće i cijele ribarske družine)' (51), śvidök (140), udovâc (168), vijatûr 'putnik' (161), vïtar (351). Imenice kojima osnova završava na -o ili -e jesu imenice tipa nöno (653), Mîho (255), odnosno Síbe (205). Potonjim je imenicama u svima padežima osnova proširena konsonantom -t- izim u nominativu i vokativu jednine: nönota $\mathrm{G}$ jd. (99), Mîketa $\mathrm{G}$ jd. (109), Môteta G jd. (104), Bôźotu D jd. (213), Viśkota A jd. (103), makãkota '1. majmun; 2. loš čovjek; 3. budala' A jd. (296), Jûreton I jd. (243).

\section{Genitiv jednine}

U genitivu je jednine sustavan nastavak -a: avukãta 'odvjetnik, advokat' (151), bãrda (105), bobä (291)/bobâ (291), bônka 'klupa' (351), bumbōkâ 'pamuk' (95), cimitêrija 'groblje' (194), dima (43), ditmãna 'mladić' (256), Fōrâ 'Hvar' (192), frementūnâ 'kukuruz' (209), glôśa (359), jôrbula 'jarbol' (61), kökota 'pijetao' (41), kominä 'kamin' (99), konopâ (162), krãja (40), krüha (199), lavûra 'rad, posao' (55), nōcïna 'način' (238), oficija 'molitvenik' (138), öglova 'ular' (183), oltōrâ (333), popâ (192), pöta 'lonac' (42), pūtâ $(46,100)$, rãta (86), śijôvca (68), śïra 'sir' (297), śmīhâ (63), śmrīcâ 'vrsta grma' (43), śtolâ (200), tarbüha (43), trūdâ (57), vapôra (275), vîka 'vijek' (47), źepâ 'džep' (219), żéśa 'gips' (327), źivotâ (40), źünja 'lipanj' (59). Neki su od primjera imenica s proširenom osnovom: nönota (99), Mîketa $(99,163,186)$, bâkota (104), Môteta (104), Tîtota (154), Ivetâ (168), Tôneta (168).

Dativ i lokativ jednine

Nastavak se $-u$ dosljedno javlja u dativu i lokativu imenica muškoga roda: bekōrü 'mesar' (187), bögu (333), boleśnīkü (334), brīgü (60), brodü (40), 
covïku (149), dōnü 'dan' (68), dvōrü (118), kantinōlü 'noćni ormarić' (327), kökotu (41), komadôntu (312), krōjü 'kralj' (352), levütu 'vrsta ribarskoga broda' (84), likōrü (192)/likōrû (194), mëdu (161), müśtu (138), mûźu (292), nośü (352), öbicoju (55, 149), ӧсu (142), pajî́z 'urbano naselje' (168), pūkü (335), pūtü (204), rãtu (86), sînu (89, 269), śtolü (42), śtrōhü (342), śudôriću 'rubac' (275), śúdü $(151,217)$, śũlcu 'sudac' $(152,157)$, śvićōrü $(57,71)$, śvidokü $(220)$, śvītü (46), tarbühu (55), tlehü (351), vijatūrü (294), vikkü 'vijek' (329), vōrhü (183), źepü (275), źvoncḯu (204). Pojedine imenice s proširenom osnovom također imaju nastavak -u: Śtrî́śkotu (164) (prema Śtrî́ko (165)), Síbetu (205) (prema Síbe (205)), Sîmetu (207), Bôźotu (213), îvotu (219).

\section{Akuzativ jednine}

U akuzativu su jednine potvrđeni dvojaki nastavci koji zavise o tomu imenuje li se imenicom što živo ili neživo. Oblik je akuzativa jednine jednak nominativu jednine ukoliko imenica označava živo, odnosno oblik je akuzativa jednine jednak genitivu jednine ukoliko imenica označava neživo. Primjeri su za živo: covīka (85), komandīrâ (166), lażîvca 'lažljivac' (213), mûża (72), öca (161), pülića 'pule' (187), śũlca 'sudac' (154), śvićōrâ (55, 57). Primjeri su za neživo: barîl 'vrsta drvene bačvice'(55), bûb 'bob'(291), fundamênt 'temelj' (40), garkijôn 'grkljan' (359), gnjûj 'gnoj' (44), grûżd 'grozd' (76), güc 'vrsta barke oštre krme' (207), jôrbul (61, 310), kapöt 'kaput' (101), katrôm 'katran' (325), kolnjîk 'suhozid' (87), kontrabônd 'krijumčarenje' (159), kordûr 'hridinasta obala' (46), kupüśs (209), librïć 'bilježnica' (298), mîr 'zid' (186), ögonj (43), ôrgan 'orgulje' (335), ormarûn 'ormar' (139), plõmik 'plamen' (352), prôg 'prag' (140), pût (46), rêp (94), sîr (42), śk̂uj 'otok' (39), śkvêr 'brodogradilište' (39), śpanjulët 'cigareta' (192), temûn 'kormilo' (53), veśtîd 'odijelo' (275), źãhod (175), zeêp (199). Hipokoristici i neke imenice imaju proširenu osnovu i nastavak -a: Viśsota (103, 174), Jêreta (200), Bốota (213), Ivota (218, 220), Mîhota (255) (prema Mîho (255)), Dûndota (294) (prema Dûndo (294)), makãkota (296), Źênśota (302) (prema Źênśo (302)), Môteta (359) (prema Môte (359)).

\section{Vokativ jednine}

U vokativu jednine, bez obzira na nepalatalni ili palatalni konsonant (i negda palatalni $r$ ) na dočetku osnove imenica, cirkuliraju nastavci -e i -u: brãte (81, 210, 355), drûże (165), kûme (85, 107), kumpôre '1. kum; 2. prijatelj' (107, 165); farabütu 'prevarant, nevaljalac' (88), lupëżu (87), svïćaru (65), śvîtu (142). U manjem je broju primjera evidentiran nastavak -o: śântulo 'kum' (88), sînko (175). Nekoliko je primjera za hipokoristike: Sîme (102), Ive (160), Jûre (243), Frône (255), Mîho (256), Ônte (294), Źênśo (302), Pêre (303). 
Instrumental jednine

U instrumentalu jednine imenica muškoga roda na palatalni konsonant, kao i u osnova s dočetkom na -c, češće nastupa nastavak -on: gôncon (gãnac 'vrsta kuke') (60), macïćon 'duša nekrštena djeteta' (99), mîrlićon 'čipka' (192), putḯon (358), siićicon (174), śúlcon 'sudac' (154), tovarcïćon (358), ali je ovjeren i poneki primjer s -en: kjūcên (364), krīżên $(76,357)$. Nastavak -on dolazi i u imenica na nepalatalni konsonant: brãton (356), brödon (39), dimon (330), mîhon (54), obïdon (332), pãrśton 'prst' (142, 175), pūtên (44), śusìidon (75), tavulînon 'manji stol' (102), zî́don (125), kod kojih se pod dugim silaznim akcentom, koji utječe na promjenu vokala, ostvaruje i -en: ${ }^{6}$ śpōgên 'konopčić' $(43,287)$, śtolên $(42,140)$, źivotên (175). Hipokoristici imaju proširenu osnovu: Îvoton (218), Jûreton (243), Frôneton (255).

\section{Nominativ množine}

Nominativ množine sustavno ima nastavak -i: avukãti (153), bancïći (87), dupïni (271), fabrikônti 'tvorničar' (70), feralići (342), ferōlì (186), fundamênti (40), guśãari (40), impjegôti ‘činovnik' (193), kolnjīcì 'suhozid' (87), kurênti 'morska struja' (68), likōrï (96), mejōsî (149), mëśtri '1. učitelj; 2. majstor' (41), pĩvci (63), rïbori (47), śiromãśi (332), śtûmci 'trbuh' (61), śvićórï (84), tônci (125), uśênci (56), vojnīcī (175).

Štokavska je duga množina opozitna čakavskoj i kajkavskoj kratkoj množini pa se u dijalektološkoj literaturi smatra morfološkim razlikovnim kriterijem. U komiškomu se govoru konsekventno ostvaruju kratki množinski oblici jednosložnih i dijela dvosložnih imenica muškoga roda, odnosno oblici bez proširenih osnova formantom -ov- ili -ev-: pūtì $(46)$, brödi $(51,325)$, kûmi (88), mïśi (232), poślì (256), pūtì (46), síni (361). U nastavku se donosi još primjera kratke množine.

\section{Genitiv množine}

U genitivu su množine imenica muškoga roda zastupljeni trojaki nastavci: $-\varnothing,-i h$ i rjeđe $-u(v)$. Reparticija je prvih dvaju nastavaka neravnomjerna, pa znatno preteže -ih: brödih $(40,75)$, brôvih (95), carnjülih 'vrsta sitne morske ribe tamnosmeđe boje' (207), dinarih (292), dölorih (312), dupïnih (271), fjurînih 'forinta' (213), guśãrih (40), kökotih 'pijetao' (295), kvintõlih 'sto kilograma' (69), lemũnih (125), mêtrîh (39, 42), milũnih (287), miśécîh (76), murlücih 'oslić' (295), retãjih 'otpadak' (329), rogõcih (100), śamõrih 'samar' (88),

$6 \quad$ Usp. M. HRASTE, 1937, 149. 
śkêrcih 'šala' (184), śusîldih (193), teźõoih (99), tovãrih (95), vïcijih 'zabava' (267), źivötih (42), no dolazi nekoliko primjera s praznim nastavkom: dôn (47, 274), Türok (39), uśënok (55). Treći se nastavak -u(v) opaža u imenici grĩhu(v) (pored grihîh) (615).

\section{Dativ, lokativ i instrumental množine}

Potrvena je razlika između dativa, lokativa i instrumentala množine imenica muškoga roda, pa je u svima primjerima potvrđen sinkretički nastavak -ima: budëlima 'jedna od četiri dijela mreže za srdele' (51), carnjūlima (208), deśkûrśima 'razgovor' (255), gardelînima 'češljugar' (359), kantinōlìma (327), milicionērïma (155), mõrtvima (358), mūlìma (293), peśtima 'šaka' (267), poślìma (292), pütïma (46), śiromãśima (332), śkojïma (39), tovãrima (186), źepïma (193), źūbïma (60). U izoliranomu se primjeru kao petrefakt u lokativu množine pojavio stari nastavak -ih: źëpih (276).

Akuzativ množine

U akuzativu je množine redovito registriran nastavak -e: bĩjce 'vrsta pokrivača' (56), bröde (270), brôve (95), carnjūlë (207), jažỉke (162), komunïste (169), kvintōlë (76), lancūnë 'plahta' (99, 192), lemūnë (125), macìce (99), milūnë 'dinja' (286), mïśe (232), mrôve (175), nöśe (351), pūtë (46), rogōcë (44), śavurnōlë 'odron šljunka' (183), śpūzeẻ (271), śtûpe (86), źmūlë ‘čaša' (125), źûbe (186).

\section{Vokativ množine}

U vokativu je množine potvrđen nastavak -i: levütoriiii ‘član posade broda leuta' (65), źemjorâlnici (85), râlnici (85), tovãri (300).

\subsubsection{Imenice srednjega roda}

Zbirne se imenice tipa lǐsće mijenjaju po jedninskoj deklinaciji imenica srednjega roda.

Imenice pluralia tantum tipa vrõta (140) mijenjaju se po množinskoj paradigmi imenica srednjega roda: vrôt (140), vrôtima (195).

Imenice se öko i üho u jednini deklinaraju po obrascu srednjega roda, dok se u množini dekliniraju prema imenicama $i$-vrste.

Imenica je dītë (94) sačuvala karakteristike nekadanje t-promjene, pa u kosim padežima ima proširenu osnovu konsonantom -t-: ditëta (234), ditëton (235). Značenje množine, pak, pokriva imenica dicâ koja se deklinira po jedninskoj deklinaciji $e$-vrste: dicê (192), dìco (267). 
Relikti su negdašnje $n$-deklinacije evidentirani u oblicima nekih imenica: vrïmena $\mathrm{G}$ jd. $(59,108)$, vrïmenu $\mathrm{DL}$ jd. (55), vrïmenon (108), vrimenâ $\mathrm{N}$ mn. (40, 256); brïmena $\mathrm{G}$ jd. (183); jümenon (312); rãmena $\mathrm{G}$ jd. (82, 103, 163, 210), rãmenu L jd. (103).

Relikti su negdašnje $s$-deklinacije ovjereni u oblicima nekih imenica, primjerice cudeśâ (171).

Deklinacijski obrazac:

\begin{tabular}{|c|c|c|}
\hline & jednina & množina \\
\hline nominativ & $-o,-e$ & $-a$ \\
\hline genitiv & $-a,-o$ & $-\varnothing,-i h$ \\
\hline dativ & $-u$ & $-i m a$ \\
\hline akuzativ & $-o,-e$ & $-a$ \\
\hline vokativ & $-o,-e$ & $-a$ \\
\hline lokativ & $-u$ & $-i m a$ \\
\hline instrumental & $-o n,-e n$ & $-i m a$ \\
\hline
\end{tabular}

Nominativ, akuzativ i vokativ jednine

U nominativu, akuzativu i vokativu jednine imenica srednjega roda stoji nastavak -o u imenica nepalatalnih osnova ili -e u imenica kojima osnova završava na palatal: bãrdo (341), cüdo (99), drũstvo (109), jõpno 'vapno' (41), jügo (93, 194), krelö 'krilo' (60), lnö 'dno' (139), mêśo (312, 357), mïśto (41), mlīkö (42), pĩśmo (150), pjüśḱlo 'mamac za lignje' (94), reśetö (139), śelö (242), sildro (51), śterãlo 'mjesto gdje se steru mreže' (59), śtrãsílo (357), üho (342), źōlö (55); godiśće (232), gröźje (75), īcê (341), loźjê 'vinograd' (287), orüje (41), pīcé (341), primãliće 'proljeće' (233), raśvanüće (59), śãrce (354, 355), śmécê (163), śûnce (81, 271, 310), svanüce (204), veśêlje (186), źlamẽnje 'znamenje' (99).

\section{Genitiv jednine}

$\mathrm{U}$ genitivu jednine dolazi nastavak $-a$, a u određenim slučajevima $\mathrm{i}$ nastavak -o. Imenice na -je i -išće imaju u genitivu jednine nastavak -o: brõnjo (86), govorẽnjo (275), iskõnjo (139), loźjô (287), pokajõnjo (255), tribjẽnjo (271), veśéljo (272), źdrôvjo (341), odnosno godiśćo (75, 269), Śtüpiśćo (Śtüpiśće 'rt pored Komiže') (61). U ostalim je primjerima markiran nastavak -a: cüda (194), jüga (194), öka (169), mêśa (357), mlīkâ (335), ölova (195), súśístva (138), vīnâ $(88,154,312)$. 
Dativ i lokativ jednine

U dativu i lokativu jednine stoji nastavak -u: cüdu $(55,299)$, kantõnju 'pjevanje' (238), karśćẽnju (88), loźjû (68, 75, 301), rïlu (257), śûncu (170), veślü (270), źlōtü (310), źólû (63).

Instrumental jednine

Nastavci su -on i -en karakteristični za instrumental jednine imenica srednjega roda: drüstvon (295); imõnjen (234), ûljen $(332,333){ }^{7}$

Nominativ, akuzativ i vokativ množine

Imenice srednjega roda u ovima trima padežima imaju nastavak -a: kolïna (87, 94, 151), olovâ (70), śelâ (210), veślâ $(42,51,71)$.

Genitiv množine

U genitivu množine srednjega roda dominira prazni nastavak: gödiść (68), gövon (125), jôj (72), kölin (86, 185), köpit (95), lëbor (203), lît (269), no prisutan je i nastavak -ih: kölih (70). U govoru se u istih primjera ukrštavaju oba nastavka, što potvrđuju dublete lebrîh i lëbor (640).

Dativ, lokativ i instrumental množine

U svima je primjerima ovjeren sinkretički nastavak -ima: bãrdima (341, 342), jïdrima (183), ślovïma (192).

U usamljenomu se primjeru jōjîh (203) u lokativu množine javlja stari nastavak $-i h$.

\subsection{Imenice e-vrste}

Drugoj $e$-vrsti pripadaju imenice ženskoga gramatičkoga roda na - $a$.

Ovdje su uključene i one imenice čija gramatička kategorija roda nije sukladna izvanjezičnoj kategoriji spola tipa kapopöśta 'zapovjednik' (206), remëta 'crkvenjak' (679) i sl.

Po $e$-vrsti dekliniraju se imenice kojih se jednina mijenja prema $a$-vrsti imenica muškoga ili srednjega roda, odnosno imaju samo gramatičku jedninu pa ih se može smatrati kao singularia tantum, primjerice dìtë - dicâ.

U deklinaciju $e$-vrste ulaze i imenice pluralia tantum tipa gãce (52), trïnoge 'tronožac' $(205,206)$ i sl.

7 V. navedeno o instrumentalu jednine imenica muškoga roda. I za srednji rod vrijede primjeri tipa celên 'čelo' (podatak s terena). 
Deklinaciji je $e$-vrste pripojena imenica stare $r$-osnove mãter (142): mãtere G jd. (207), mãteri $\mathrm{DL}$ jd. (208, 232), mãterun (242), a isto tako i imenica 'kokoš' izvorno i-osnove: kökośe A mn. (297).

Imenice se negdašnjih v-osnova tipa crîkva dekliniraju kao imenice $e$-vrste.

Deklinacijski obrazac:

\begin{tabular}{|c|c|c|}
\hline & jednina & množina \\
\hline nominativ & $-a,-e,-\varnothing$ & $-e$ \\
\hline genitiv & $-e$ & $-\varnothing,-i h$ \\
\hline dativ & $-i$ & $-a m i,-$ ima \\
\hline akuzativ & $-u,-\varnothing$ & $-e$ \\
\hline vokativ & $-o,-e,-a,-\varnothing$ & $-e$ \\
\hline lokativ & $-i$ & - ami, -ima \\
\hline instrumental & $-u n$ & $-a m i,-$ ima \\
\hline
\end{tabular}

Nominativ jednine

U nominativu jednine dolaze nastavci $-a$, -e i $-\varnothing$ : borovïna (351), cigarjêra 'cigaršpic' (299), deźgrãcija 'neprilika, nesreća' (138), grihotâ (44), íżbina 'jelo' (204), jaglìca 'iglica' (94), jemãtva 'vrijeme berbe grožđa' (353), kãrśnica 'imendan' (61), katrîdica 'stoličica' (312), kośćìca (58), lãta (162), lõja 'svjećarica' (65), mïśa 'misa' (326), muhâ (86), nedija (68), nevêra (39), pêgula 'nesreća' (63), peśkarïja 'ribarnica' (295), pïpa 'slavina' (174), rīkâ (175), śceetta (299), śküla (46), śkurinâ 'tama, mrak' (359), trōvä (86), tünja 'vrsta naprave za ribolov' (94), tvïca 'ptica' (140), źermôna 'rođakinja' (174), źōtèga 'dio ribolovne družine' (62); gãće (52), trïnoge 'tronožac' (205, 206); mãter (142).

Genitiv jednine

Genitiv jednine sustavno ima nastavak -e: balônce 'vaga' (295), bônde (40), crĩkve (325, 357), dajinê (294), glōvê (41, 169), guśtîrne 'zdenac, cisterna' (139), hudobê 'đavao' (108), jaglice (94), kanãve 'vrsta suhe trave (npr. za sukanje konopa)' (94), kãsse 'mrtvački sanduk' (76), lopãtice (57), mūkê 'brašno' (68)/mukê (209), ośköruśe 'vrsta voćke' (100), partênce 'polazak' (167), pjacëte (183), ponïstre (103), pośtëje (359), prôve 'pramac' (207), rîve (342), roźgê 'trstika' (299), śküle (125), ślãme (42), śmökve (267), śpïlice (60), śpîne 'slavina' (175), śuźê (332), trãte 'vrsta mreže potegače' (51), trōvê (86), vodê (174), źīmê (154), źorê (68). 
Dativ i lokativ jednine

Dativ i lokativ jednine imenica ženskoga roda imaju nastavak - $i$ : drużïni (51), facêndi (95), glōvï (55, 205), gośpodarïci (75), jemãtvi (75), lumbrëli (159), milĩciji (159), nevöji (332), pulïtici (170), rïbaśćini (55), rîvi (342), śkurinï (93, 187), vodì (184), źêmji (150), źenï (83, 88, 233), źvīźdì (341).

Akuzativ jednine

Pored praznoga nastavka u imenice mãter (142) u akuzativu je jednine za palatalne i nepalatalne osnove dominantan nastavak - $u$ : argütulu 'rudo kormila' (85), bandîru 'zastava' (270), banïcu 'vrsta austrougarskoga sitnoga novca' (102), berïtu 'kapa' (154), blażïnju 'jastuk' (234), cëśtu 'cesta' (358), crīkvu (41), divïcicu 'zjenica' (169), drużīnu (288), dubinü (44), fanterïju 'pješadija' (268), fibru 'povišena tjelesna temperatura' (47), galiju (39), glôvu (276), glôvu (41), jandarmerïju 'žandarmerija' (206), jôglu 'igla' (169), konöbu (139), kūlü (40), lemunôdu (125), lëtriku (86), lumëtu 'uljanica' (202), mûltu 'novčana kazna' (298), mũrvu (118), petrôru 'kamenolom' (41), potrïbu (51), rãpu 'rupa' (59), śpicjarïju 'ljekarna' (194), śvićcù (359), taramëju 'metež, uzbuna, skandal' (142), têndu 'cerada' (51), trōvü (44), vãlu 'uvala' (40), vïścicu 'vještica' (72), vödu (174), võjśku (175), vríću (86), źálbu (153), źêmju (39), źurnôtu 'dnevnica, nadnica' $(86,206)$.

\section{Vokativ jednine}

Pored praznoga nastavka u imenice mãter (142) u vokativu je jednine posvjedočen nastavak -o: môjko (353), śëśtro (140,141, 354), vôjśko (175) dok se nastavak -e pojavljuje u imenica tipa Mâre (205), odnosno nastavak - $a$ u imenica tipa Domîna (140), Vĩnka (140), Rejîna (274), Bûrtula (332).

\section{Instrumental jednine}

U svima je primjerima ovjeren nastavak -un $(<-$ on $)$ : bracêrun 'vrsta jedrenjaka' (104), brãmun ‘žurba' (184), brîvun 'brzina' (174), drużīnun (327), famïjun (46), glōvûn $(55,184,276)$, incerôdun 'kabanica' (158), jōglûn (169), kacjôlun 'zaimača' $(125,206)$, köfun 'košara' (68), kośerãcun 'vrsta alata' (46), nogûn (60), pëcun 'krpa' (204), rōśpütnicun 'prečac' (99), rūkûn (60, 267), śãbjun 'sablja' (107), śardëlun (184), tajêntun 'vrsta klesarskoga čekića' (46), Venêcijun (39), vodûn (312), źemjûn (311), źenûn (83, 234), żörun (62), żvī́dûn (343). 
Nominativ, akuzativ i vokativ množine

Navedeni padeži dosljedno imaju nastavak -e: banïce 'vrsta austrougarskoga sitnoga novca' (200), besiỉde (95), bëśtije (44), bûmbe 'bomba' (186), ceśmïne (39), cïme 'kraj konopa' (275), cukadële 'suhi korijen makije (za ogrjev)' (44), drãce (46), dûśe (108), glavnjïce 'zapaljeno drvo' (110), jakëte (55), koćetîne 'krevetić' (139), kolûmbe 'brodska kobilica' (40), kośćīce (58), kośerãce (88), kupïne (46, 184), mãske (232), mrïźe (51), nöge (168), parśurãte (202), päucine (46), plöce (95), pojãce 'slamnjača' (55), pölkove (95), rãpe 'rupa' (95), śardële (59), śiromãśice (297), śkûse 'vrsta plave morske ribe' (69), śôlpe 'vrsta morske ribe, salpa' (289), śpurtênjace '1. gajeta i njezina posada s mrežama sardelarama; 2. mreža srdelara; 3 . način lova srdela' (51), śtîne (41), śüśte 'donji madrac s federima' (139), śvićëe (108), vrïce (86), źãlbe (153), źvī́dë (111).

\section{Genitiv množine}

U genitivu su množine imenica ženskoga roda usporedo ovjereni nastavci -ø i -ih: banîc (200), beśîd (195), cêl 'pčela' (161), gîr (83), kãrot (199), karticêl 'stranica' (152), lìtor (210), mãślin (297), mrîź (95, 271), parśurôt 'vrsta uštipka' (202), śardêl (59), śmökov (297); bëśtijih (95), beśtimih (62, 64), bôndih (140), ceśmïnih (41), güśćericih (42), incerôdih 'kabanica' (159), kacötih 'šaka' (202), kënjih 'magarica' (95), pölkovih 'potkova' (95), śkarpînih (295), śpãrtih 'košara od pruća' (94), ûrih (162). Reparticija je ovih nastavaka nejasna, tj. izgledno je da mnoge imenice mogu imati ili jedan ili drugi nastavak. Potvrdom su dublete dïnjih 'lubenica' (287) i dînj (287), kośerôc i kośerãcih (635), lìgonj (207) i lîgnih (94), mudãnot i mudôntih (647), ûź i üżih (705).

Dativ, lokativ i instrumental množine

U dativu, lokativu i instrumentalu množine alterniraju nastavci -ami i -ima bez jasnoga distribucijskoga kriterija: banïcami $(200,201)$, butĩgami 'dućan' (275), grōnãmi (267), köficami 'omanja košara' (167), metlãmi (201), motïkami (83), mrïźami (59, 217), nogãmi (103, 257), püśkami (312), roźgãmi (299), śtinãmi (294), tûrticami 'manji okrugli kruh' (200); argütulima 'rudo kormila' (84), dìnjima (288), incerôdima (158), kãpjicima (353), lopãticima (55), molitvima (110), pölkovima (95), śãbjima (310), śvêrima 'kazaljka sata' (200). Čini se, sudeći po primjerima rūkãmi (103) i rūkïma (175), da se kod istih imenica mogu pojaviti ili jedan ili drugi nastavak. 


\subsection{Imenice $i$-vrste}

Po trećoj se deklinacijskoj vrsti mijenjaju imenice ženskoga gramatičkoga roda koje u genitivu jednine imaju nastavak $-i$. Takvih imenica nije velik broj $\mathrm{i}$ mnoge se ne govore u množini.

Ovamo se uvrštavaju i neke imenice bivše v-osnove poput jubôv (63)/ jūbôv $(238,239)$.

Imenice su ugasle $s$-osnove öko i üho u množini priklonjene imenicama $i$-vrste.

Deklinacijski obrazac:

\begin{tabular}{|c|c|c|}
\hline & jednina & množina \\
\hline nominativ & $-\varnothing$ & $-i$ \\
\hline genitiv & $-i$ & $-i j u,-i h$ \\
\hline dativ & $-i$ & $-i m a$ \\
\hline akuzativ & $-\varnothing$ & $-i$ \\
\hline vokativ & $-i$ & $-i$ \\
\hline lokativ & $-i$ & $-i m a$ \\
\hline instrumental & $-j u,-i$ & $-i m a$ \\
\hline
\end{tabular}

Nominativ i akuzativ jednine

U nominativu je i akuzativu jednine nastavak - $\varnothing$ : barbaritôd 'strahota' (333), jubôv (63)/jūbôv (238, 239), kûs't (58), mlãduśt (267), nûć (39, 71, 293), rîc (233), śmârt (364), śtãruśt (46, 267), śûl (271), śvïtlośt (332), vëcer (102).

Genitiv jednine

Genitiv jednine ima nastavak -i: korïśti (42,355), nöći (70), pömoći (63), śôli (271), śvïtlośti (93), vëceri (218), źãlośti (149).

\section{Dativ i lokativ jednine}

U obama je padežima nastavak -i: mlãdośti (267), noćỉ (87), śmãrti (142), śtãrośti (267).

\section{Vokativ jednine}

U vokativu je jednine registriran nastavak -i: źãlosti $(149,354)$.

$\underline{\text { Instrumental jednine }}^{8}$

$\mathrm{U}$ instrumentalu su jednine evidentirani nastavak $-j u$ te nastavak $-i$ : jubãvju/jubãvi, źãlośti.

8 Za ovaj padež nije bilo potvrda u materijalu, stoga su se iznimno koristili terenski podatci. 
Nominativ, akuzativ i vokativ množine

Navedenim je padežima svojstven nastavak -i: köśti (57, 271), nöći (330), novitôdi (256), öci (93, 271), rîci (91).

Genitiv množine

U genitivu je množine posvjedočen -ih u primjeru noćîh (341), ali i stari dvojinski nastavak -iju u primjerima ocïju (352), parśïju (154), usíiju (298).

Dativ, lokativ, instrumental množine

Sinkretički je nastavak -ima prevladao u dativu, lokativu i instrumentalu množine: ocïma (304), usímma (358).

\section{Zaključak}

$\mathrm{Na}$ temelju se pouzdane građe iz opsežnoga djela Viški facendijer. Stil, leksik, svijet facende otoka Visa dvadesetoga stoljeća Joška Božanića izdvajaju vlastitosti u deklinaciji imenica u mjesnomu govoru Komiže na otoku Visu. Važne su činjenice: lokativ jednine muškoga i srednjega roda s nastavkom $-u$; kratke množine jednosložnih i dijela dvosložnih imenica muškoga roda bez proširka; prazni nastavak u genitivu množine te nastavak -ih u svima trima rodovima, a u manjem broju imenica muškoga roda i $-u v(<-o(v))$; sinkretizam na -ima u dativu, lokativu i instrumentalu množine imenica muškoga i srednjega roda, odnosno kolebanja između -ami i -ima u tima padežima u imenica ženskoga roda; akuzativ množine muškoga roda na -e. Analiza je pokazala da su osobitosti u deklinaciji imenica opserviranoga govora većinom očekivane za govore srednjodalmatinskoga područja te da nisu uzdrmane najnovijim utjecajima i nanosima sa strane.

\section{Izvori i literatura}

Joško BOŽANIĆ, Viški facendijer. Stil, leksik, svijet facende otoka Visa dvadesetoga stoljeća, Split, 2015.

Lucija DOROTIĆ, Komiški govor, studentski rad u rukopisu.

Filip GALOVIĆ, Dijalektološke zamjedbe o mjesnome govoru Slatina na otoku Čiovu, Ethnologica Dalmatica, 25/1, Split, 2018, 137-145.

Filip GALOVIĆ, Govor Donjega Humca, Jezikoslovlje, 15/2-3, Osijek, 2014, 231267. 
Filip GALOVIĆ, Jezične osobitosti mjesnoga govora Ložišća na otoku Braču, Fluminensia, 25/1, Rijeka, 2013, 181-198.

Filip GALOVIĆ, O govoru starijih Splićana, U: Dunja Jutronić, Spliske riči. Rječnik: hrvatski standardni jezik - splitski govor, Split, 2018, 13-25.

Filip GALOVIĆ, O pitavskome idiomu iz pera Pitovke, U: Tašenka Matulović, Amarcord po našu, Split, 2015, 8-17.

Mate HRASTE, Čakavski dijalekat ostrva Brača, Srpski dijalektološki zbornik, 10, Beograd, 1940, 3-66.

Mate HRASTE, Čakavski dijalekat ostrva Hvara, Biblioteka Južnoslavenskog filologa 8, 1937.

Mate HRASTE, Osobine govora ostrva Visa, Zbornik u čast A. Belića 2, 1937, 147154.

Mate HRASTE, Osobine govora otoka Šolte, Čiova Drvenika i susjedne obale, Rad JAZU 272, 1948, 123-156.

Pavle IVIĆ et al., Fonološki opisi srpskohrvatskih/hrvatskosrpskih, slovenačkih $i$ makedonskih govora obuhvaćenih opšteslovenskim lingvističkim atlasom, Sarajevo, 1981.

Martina KUZMIĆ, Sklonidba imenica u zlarinskome govoru, Hrvatski dijalektološki zbornik, 18, Zagreb, 2013, 175-186.

Josip LISAC, Hrvatska dijalektologija 2: Čakavsko narječje, Zagreb, 2009.

Josip LISAC, Veliko djelo Joška Božanića, Zadarska smotra, LXV/1-2, Zadar, 2016, 306.

Iva LUKEŽIĆ, Imenička sklonidba u sjevernočakavskim dijalektima u 20. st., Hrvatski dijalektološki zbornik, 20, Zagreb, 2016, 129-149.

Iva LUKEŽIĆ, Padežni nastavci u sklonidbi imenica u čakavskome narječju, Od indoeuropeistike do kroatistike: Zbornik u čast Daliboru Brozoviću, Zagreb, 2013, 247-269.

Iva LUKEŽIĆ, Zajednička povijest hrvatskih narječja. 2. Morfologija, Zagreb, 2015.

Milan MOGUŠ, Čakavsko narječje. Fonologija, Zagreb, 1977.

Petar ŠIMUNOVIĆ, Čakavština srednjodalmatinskih otoka, Čakavska rič, 7/1, Split, 1977, 5-63.

Silvana VRANIĆ, Govori sjeverozapadnoga makrosustava na otoku Pagu. 2. Morfologija, Rijeka, 2011. 


\title{
THE DECLINATION OF NOUNS IN KOMIŽA SPEECH
}

\begin{abstract}
Summary
Focussed upon in the paper is the morphological problem of the local speech of Komiža on the island of Vis, i.e. with the aim main to point out the individuality in the declination of nouns. On the basis of the analysed material it can be concluded that the peculiarities in the declination of nouns of the observed speech are mainly expected for the central Dalmatian region and that they are not disturbed by the latest influences and trends from outside.

Keywords: Chakavian dialect, morphology, declination of nouns, speech of Komiža, the island of Vis
\end{abstract}

